\begin{tabular}{|c|c|c|c|}
\hline \multirow{3}{*}{$\begin{array}{r}\text { Case Reports in } \\
\text { Gastroenterology }\end{array}$} & \multirow{2}{*}{\multicolumn{2}{|c|}{ Case Rep Gastroenterol 2016;10:269-274 }} & \multirow[b]{3}{*}{$\begin{array}{l}\text { Karger } \\
\text { Open access }\end{array}$} \\
\hline & & & \\
\hline & $\begin{array}{l}\text { DOI: } 10.1159 / 000446642 \\
\text { Published online: June 14, } 2016\end{array}$ & $\begin{array}{l}\text { (c) } 2016 \text { The Author(s) } \\
\text { Published by S. Karger AG, Basel } \\
\text { www.karger.com/crg }\end{array}$ & \\
\hline & $\begin{array}{l}\text { This article is licensed under } \\
\text { International License (CC BY-NC } \\
\text { Usage and distribution for comm }\end{array}$ & $\begin{array}{l}\text { nons Attribution-NonCommercial } 4.0 \\
\text { ger.com/Services/OpenAccessLicense). } \\
\text { uires written permission. }\end{array}$ & \\
\hline
\end{tabular}

\title{
Infected Urachal Cyst in an Adult: A Laparoscopic Approach
}

\author{
Ching-Ming Kwok ${ }^{\mathrm{a}, \mathrm{b}}$ \\ ${ }^{a}$ Division of General Surgery, Department of Surgery, Cheng Hsin General Hospital, \\ Taipei, Taiwan; ${ }^{\mathrm{b}}$ National Yang Ming University School of Medicine, Taipei, Taiwan
}

\section{Keywords}

Urachal cyst infection - Laparoscopic resection .

\begin{abstract}
Urachal cysts occur infrequently in adults and are rarely reported in the literature. Laparoscopic excision or robot-assisted laparoscopic excision of urachal cysts has widely been applied in recent years. We present a case of urachal cyst infection treated with antibiotics and two-staged operation. The laparoscopic procedure was performed without any complications. Strong suspicion is the key for early diagnosis.

(C) 2016 The Author(s)

Published by S. Karger AG, Basel
\end{abstract}

\section{Introduction}

The urachus develops when the bladder descends to the pelvis in the 5th month of fetal development, resulting in the formation of the urachal canal. The lumen of this canal obliterates during fetal life. Sometimes, however, it will become a fibrous tract in early adult life. Incomplete regression of the fetal urachus may result in some forms of abnormalities.

Most of the urachal abnormalities present in children because urachal obliteration usually takes place in early infancy. Hence, abnormalities rarely occur in adults, and there are few reports in the literature. The most common form of urachal abnormalities in adults is the urachal cyst, and infection is the usual mode of manifestation [1]. Diagnosis is somehow difficult due to its nonspecific symptoms. 
Herein we present a case of urachal cyst infection in a young adult, manifesting by an inflammation at the umbilicus treated with a two-stage operation using a laparoscopic approach.

\section{Case Presentation}

A 29-year-old healthy male presented at our emergency room with a 3-cm painful mass on the umbilicus. Yellowish pus leaked from the inflamed mass during the physical examination. He neither had fever nor other abdominal symptoms, and laboratory values were normal in the beginning. An oral antibiotic (dicloxacillin $250 \mathrm{mg}$ q.i.d.) was prescribed. However, the pain progressed the next day, and the painful area increased to $15 \mathrm{~cm}$ around the subumbilical region in the lower abdomen. Leukocytosis developed. Pus regressed, but a small amount of bloody discharge appeared. An abdominal CT scan (fig. 1, fig. 2) showed a 4$\mathrm{cm}$ mass beneath the patient's subumbilical region. An infected urachal cyst was impressed. Ertapenem $1 \mathrm{~g}$ per day was given, and a two-staged operation was considered. Ultrasonography (fig. 3) was performed after several days of antibiotic treatment.

The first operation was done through a subumbilical bracket incision and a 4-cm pocket, and a small amount of pus could be identified and drained. Treatment with antibiotics was continued, and dressing was applied to the wound. A second operation was performed 1 week after the initial drainage. The patient was put in a semi-Fowler's position. The operator stood on the right side of the patient and the assistant on the left side to hold the laparoscope. Three ports (one 5-mm port at the upper midline abdomen for a laparoscopic grasper, one 5 -mm port at the left upper abdomen for a $5-\mathrm{mm} 30^{\circ}$ laparoscope, and one 3-mm working port over the right upper abdomen) were created. Transection of the fibrotic tract was done in the pelvis, and endoclips were applied near its insertion into the urinary bladder. The urachal cyst and the fibrotic tract were resected, and the specimen was removed through the umbilicus. The operation was completed in 60 min with minimal bleeding. The postoperative course was uneventful, and the patient did well during follow-up at our outpatient department. The pathology reports indicated acute and chronic inflammation with dense fibrotic tissues. No evidence of malignancy was noted.

\section{Discussion}

The first to describe urachal abnormality was Cabriolus in 1550. Since then, few cases had been reported in the literature. The urinary bladder descent into the fetal pelvis in the 5th month of development pulls the urachus, leading to the formation of the urachal canal. The lumen of the canal progressively obliterates during fetal life.

Five types of urachal abnormalities were defined: (1) patent urachus, where the entire tubular structure fails to close; (2) urachal cyst, where both ends of the urachal canal close, leaving an open central portion; (3) urachal sinus, which drains proximally into the umbilicus; (4) vesicourachal diverticulum, communicates distally with the urinary bladder, and (5) alternating sinus, which can drain to either the bladder or umbilicus [2]. The incidence of an urachal cyst in adults is unknown but is rare. It is more common in males than females $[1,3]$. The most common presentation of urachal abnormality is the urachal cyst, with infection being the usual symptom displayed [3,4]. Commonly cultured microorganisms from the cystic fluid include Escherichia coli, Enterococcus faecium, Klebsiella pneumonia, Proteus, 
Streptococcus viridans and Fusobacterium [3, 4]. Our culture report was negative due to the late collection of the sample.

Clinical signs and symptoms are nonspecific and can only be identified when infection occurs. The presence of the triad of symptoms including a tender midline infraumbilical mass, umbilical discharge and sepsis should raise suspicion of urachal cyst infection. Our patient presented with similar symptoms; strong suspicion is the key to achieve the final diagnosis of urachal cyst infection.

Once an urachal cyst is suspected, diagnosis can be made easily by abdominal ultrasonography [4] or computed tomography [5]. We used computed tomography for the diagnosis, followed by ultrasonography to confirm the extent of the lesion toward the fibrotic tract.

Treatment of urachal cysts is complete excision due to the risk of malignant transformation. Single-stage excisions result in significantly more complications and longer hospitalization, whereas the two-stage approach, i.e., an incision and drainage followed by a secondary excision, is usually complication free $[4,6]$. However, the optimal treatment method remains a subject of debate. The advancements in antibiotics and imaging studies make the single-stage treatment more feasible [7]. Nevertheless, several reports suggest that twostage procedures lead to a shorter hospitalization and are complication free [6, 8]. We used the two-stage excision, which was complication free.

Technical advancements and growing experience make the laparoscopic excision of urachal cysts a simple procedure, and better outcome can be achieved. Several reports using laparoscopic excision [9, 10] or robot-assisted laparoscopic excision [11] of urachal cysts have been reported. Usually, three conventional ports $(10,5$, and $5 \mathrm{~mm})$ are applied. In our patient, the laparoscope was introduced through the upper midline port. We applied three ports $(5,5$, and $3 \mathrm{~mm})$ using a $5-\mathrm{mm} 30^{\circ}$ laparoscope to complete the procedure safely and smoothly. Our assistant handled the $30^{\circ}$ laparoscope stationary through the left-upperabdomen trocar. The operator performed the excision through the 3-mm right-upperabdomen and 5-mm upper-midline-abdomen working ports. It is a more comfortable position for the operator and assistant as they are not interfering with each other during the operation.

\section{Conclusion}

Urachal cyst is a rare condition, and only a few cases are reported in the literature. Strong suspicion is the key for early diagnosis, and urachal cyst should be kept in mind in the differential diagnosis. The two-staged operation is the better procedure for achieving a shorter hospitalization and to prevent complications. Laparoscopic excision is the ideal approach nowadays, although the optimal treatment method is still indefinite.

\section{Statement of Ethics}

The authors have no ethical conflicts to disclose. 
Kwok: Infected Urachal Cyst in an Adult: A Laparoscopic Approach

\section{Disclosure Statement}

The author declares no conflicts of interests in relation to the material presented in this paper.

\section{References}

1 Rischer WH, Sardi A, Bolton J: Urachal abnormalities in adults: the Ochsner experience. South Med J 1990;83:1036-1039.

2 Ekwueme KC, Parr NJ: Infected urachal cyst in an adult: a case report and review of the literature. Cases J 2009;2:6422.

3 Ashley RA, Inman BA, Routh JC, Rohlinger AL, Husmann DA, Kramer SA: Urachal anomalies: a longitudinal study of urachal remnants in children and adults. J Urol 2007;178:1615-1618.

4 Yoo KH, Lee SJ, Chang SG: Treatment of infected urachal cysts. Yonnsei Med J 2006;47:423-427.

5 Herman TE, Schackelford GD: Pyourachus CT manifestations. J Comput Assist Tomogr 1995;19:440.

6 Minevich E, Wacksman J, Lewis AG, Bukowski TP, Sheldon CA: The infected urachal cyst: primary excision versus a staged approach. J Urol 1997;157:1869-1872.

7 Newman BM, Karp MP, Jeweet TC, Cooney DR: Advances in the management of infected urachal cysts. J Pediatr Surg 1986;21:1051-1054.

8 Masuko T, Nakayama H, Aoki N, Kusafuka T, Takayama T: Staged approach to the urachal cyst with infected omphalitis. Int Surg 2006;91:52-56.

9 McCollum MO, Macneily AE, Blair GK: Surgical implications of urachal remnants: Presentation and management. J Pediatr Surg 2003;38:798-803.

10 Nelson MS, Richard JG, Herbert W: Laparoscopic excision of an urachal cyst. Urology 1995;45:161-164.

11 Dennis N, Kevin Y, Michael L: Laparoscopic excision of infected urachal cyst: illustration of technique. Surg Pract 2010;14:77. 


\section{Case Reports in Gastroenterology

\begin{tabular}{l|l}
\hline Case Rep Gastroenterol 2016;10:269-274 \\
\hline $10.1159 / 000446642$ & $\begin{array}{l}\text { C } 2016 \text { The Author(s). Published by S. Karger AG, Basel } \\
\text { www.karger.com/crg }\end{array}$ \\
\hline
\end{tabular} \\ Kwok: Infected Urachal Cyst in an Adult: A Laparoscopic Approach}

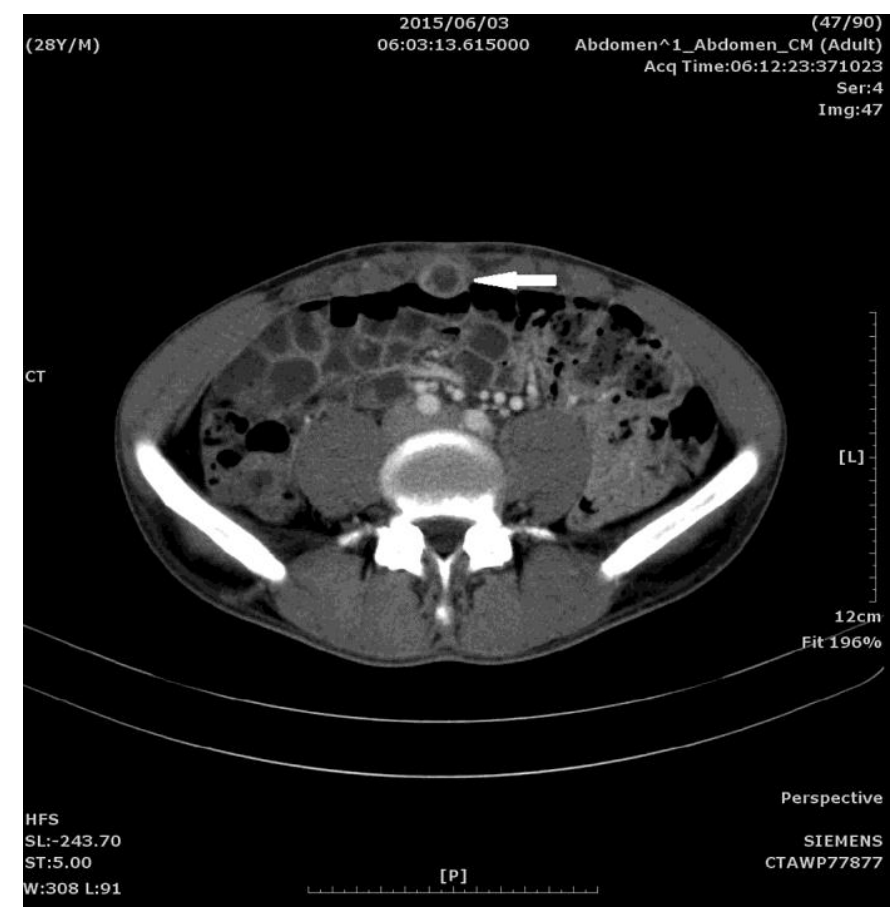

Fig. 1. Abdominal CT scan, transverse view. A 4-cm mass in the subumbilical region with abscess formation (arrow).

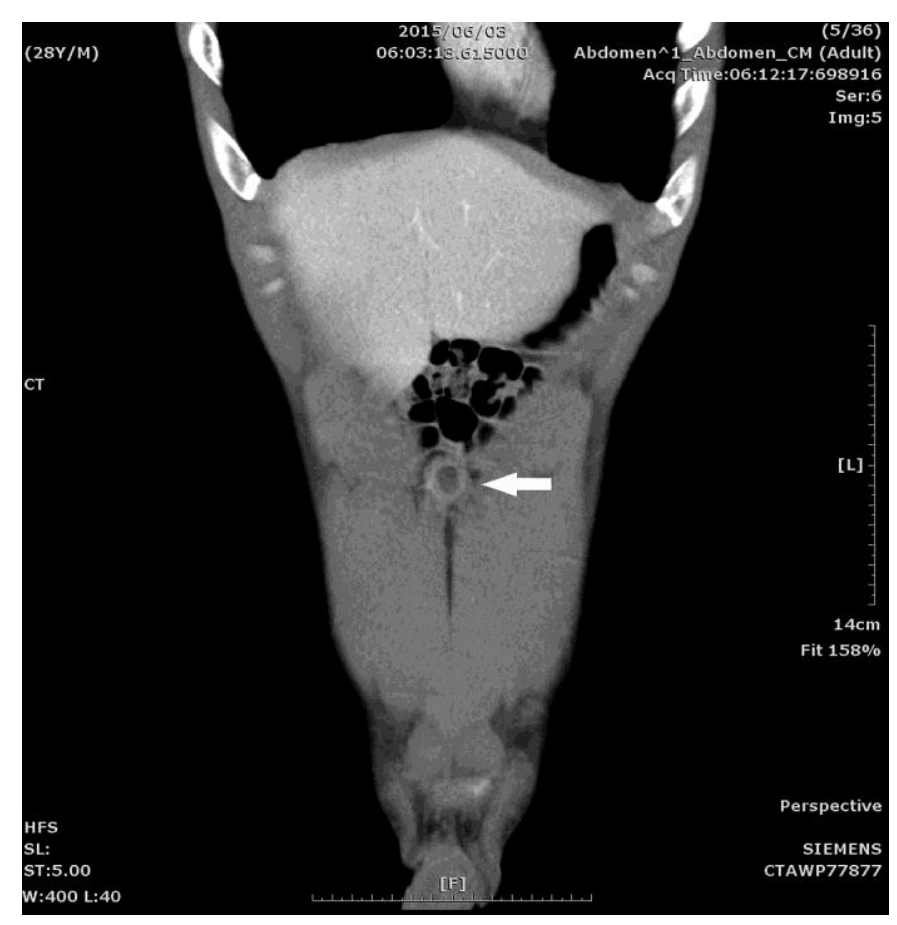

Fig. 2. Abdominal CT scan, coronal view. The same mass in the subumbilical region (arrow) with a thickening capsule and abscess formation. 


\begin{tabular}{ll|l} 
Case Reports in & \begin{tabular}{l} 
Case Rep Gastroenterol 2016;10:269-274 \\
\cline { 2 - 3 } Gastroenterology
\end{tabular} & $\begin{array}{l}\text { ○ 2016 The Author(s). Published by S. Karger AG, Basel } \\
\text { www.karger.com/crg }\end{array}$ \\
\cline { 2 - 3 } & Kwok: Infected Urachal Cyst in an Adult: A Laparoscopic Approach
\end{tabular}

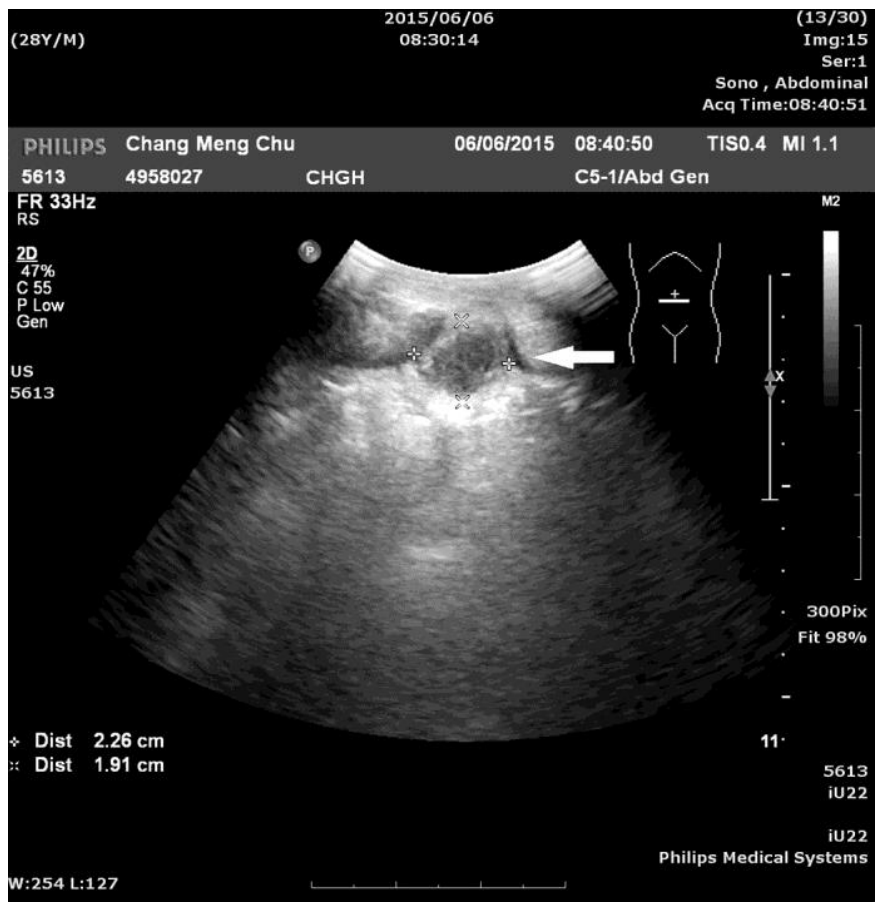

Fig. 3. Ultrasonography. A hypoechoic nodule of $3.9 \times 2.3 \times 1.9 \mathrm{~cm}$ in the periumbilical region with regional soft tissue swelling and increased vascularity (arrow). 